\title{
Why torture?
}

\author{
RUTH BLAKELEY*
}

Abstract. I develop a framework to account for torture, which I argue should be understood with reference to international relations. I show that torture is intended as a tool to ensure the security, stability and legitimacy of elites, often transnationally, but there is often a disjuncture between its intended and actual outcomes. Despite dominant claims that torture is used to defeat security threats, most torture is intended to deter political opposition and secure legitimacy for elites. I conclude that torture should be renounced, both on moral grounds, and because it is not necessary for the functions it is intended to serve.

\section{Introduction}

This article develops a framework to help account for state use and sponsorship of torture. The sponsorship of torture is referred to throughout simply as torture, on the grounds that if a state sponsors torture elsewhere, that state is using it indirectly, and is therefore complicit in its use. While its use in the 'War on Terror' has attracted attention recently, torture is underexplored, and existing theories are inadequate for explaining its functions. ${ }^{1}$ Previous research has tended to focus on why individuals use torture or on why authoritarian states have used it..$^{2} \mathrm{~A}$ few scholars have assessed the use of torture by liberal democracies, for example by the French in Algeria, and

* The author would like to thank Eric Herring, Stephen Blakeley, Bill Bowring, Rob Dover, Paul Higate, Richard Jackson, Kent Johnson, David Miller, Anna Stavrianakis, Doug Stokes, David Whyte, and two anonymous RIS referees for comments on an earlier draft of this article.

1 Alex Bellamy, 'No Pain, No Gain? Torture and Ethics in the War on Terror', International Affairs, 82:1 (2006), pp. 121-48; Alan Dershowitz, 'Is There a Torturous Road to Justice?' Los Angeles Times, 8 November 2001, p. 19; Sanford Levinson (ed.), Torture. A Collection (Oxford: Oxford University Press, 2004); Neil MacMaster, 'Torture: From Algiers to Abu Ghraib', Race and Class, 46:2 (2004), pp. 1-21; Alfred McCoy, A Question of Torture. CIA Interrogation, from the Cold War to the War on Terror (New York: Metropolitan Books, 2006); Maureen Ramsey, 'Can the Torture of Terrorist Suspects be Justified?', The International Journal of Human Rights, 10:2 (2006), pp. 103-19.

2 On the role of the individual: Stanley Cohen, States of Denial. Knowing About Atrocities and Suffering (Cambridge: Polity Press, 2001); Stanley Milgram, Obedience to Authority (London: Tavistock Publications, 1974). On torture for punishment: Cesare Beccaria, On Crimes and Punishments and Other Writings, ed. Richard Bellamy (Cambridge: Cambridge University Press, 1995); Michel Foucault, Discipline and Punish. The Birth of the Prison, trans. Alan Sheridan (London: Penguin Books, 1977). On torture in authoritarian states: Hannah Arendt, The Origins of Totalitarianism (New York: Harcourt, Brace and World, 1966); Edward Peters, Torture (New York: Basil Blackwell, 1985); Darius Rejali, 'How Not to Talk About Torture: Violence, Theory and the Problems of Explanation', in Martha Huggins (ed.), Vigilantism and the State in Modern Latin America: Essays in Extralegal Violence (New York: Praeger, 1991), pp. 127-44; Torture and Modernity: Self, Society and State in Modern Iran (Boulder, CO: Westview Press, 1994). 
by the US during the Cold War. ${ }^{3}$ The framework I develop helps to account for torture by authoritarian and liberal states. ${ }^{4}$ I argue that we can better understand torture by examining it within the context of connections across state boundaries, as well as at state level. The framework consists of three models. These are predicated on the assumption that key functions of the state are to ensure security, stability and legitimacy, primarily in the interests of elites, by which I mean those within society that own the means of production or have significant access to political power. ${ }^{5}$ Torture is intended to serve these functions.

The security model reflects the dominant claims made about torture by authoritarian and liberal states alike - that its function is to obtain intelligence to defeat security threats. The stability model accounts for torture when it is used in authoritarian states, but often sponsored by external liberal elites, as a method to instil fear, to deter potential and actual political opposition among the population. This is intended to help protect the interests of elite groups. The legitimacy model accounts for the ways in which state officials, usually from liberal states, seek, on the one hand, to secure the right to use torture, based on the assignment of specific identities of themselves - as legitimate - and of those against whom they wish to use torture - as illegitimate. On the other hand, claiming the right to use torture is intended to secure those specific identities, which are never fixed. The models are addressed individually in this article because each helps to account for different functions that are served by torture, but as I will show, there is significant overlap between them. They should not therefore be seen as mutually exclusive, but rather, mutually constitutive. As I develop each model I also explore its possible consequences, because the intended and actual outcomes of torture are not necessarily congruent.

A key question is whether there is any difference between liberal and authoritarian states with regard to torture. This is because the public discourse of liberal states is

${ }^{3}$ Pierre Vidal-Naquet, Torture: Cancer of Democracy (Middlesex: Penguin Books, 1963); La Torture Dans la République (Paris: Editions François Maspero, 1972); Noam Chomsky and Edward Herman, The Washington Connection and Third World Fascism: The Political Economy of Human Rights, vol. I (Boston, MA: South End Press, 1979); After the Cataclysm. Postwar Indochina and the Reconstruction of Imperial Ideology. The Political Economy of Human Rights, vol. II (Nottingham: Spokesman, 1979); John Conroy, Unspeakable Acts, Ordinary People: The Dynamics of Torture (London: Vision Paperbacks, 2001), which covers the use of torture by the British against IRA suspects; Alexander George, State Terrorism and the United States: From Counterinsurgency to the War on Terrorism (London: Zed Books, 2004); Edward Herman, The Real Terror Network, 2nd edn. (Montreal: Black Rose Books, 1985); Martha Huggins, Political Policing: The United States and Latin America (Durham, NC: Duke University Press, 1998); Martha Huggins et al., Violence Workers: Police Torturers and Murderers Reconstruct Brazilian Atrocities (Berkeley, CA: University of California Press, 2002), Douglas Valentine, The Phoenix Program, 2nd edn. (Lincoln: Authors Guild BackinPrint.Com, 2000).

4 I use the terms 'liberal democracy' or 'liberal state' to refer to democratic states largely situated in the global North, on the grounds that those states tend to claim to operate according to liberal democratic principles. I recognise that such states do not always comply with those principles, either politically or in economic terms, but broadly speaking they are to some extent both liberal and democratic. Defining non-democratic, non-liberal states is equally problematic, but given that such states are usually, to some extent, authoritarian, I refer to them as authoritarian states throughout.

5 This draws on functional conceptions of the state, whereby the state is defined by its consequences, not simply its organisation, and on Marxist conceptions of the state apparatus as being geared towards the political interests of capitalist elites. See Patrick Dunleavy and Brendan O'Leary, Theories of the State: The Politics of Liberal Democracy (Basingstoke: Palgrave Macmillan, 1987), pp. 3-4 and 203-70; Nicos Poulantzas, Political Power and Social Classes, trans. Timothy O'Hagan (London: Verso, [1968] 1987), pp. 130-91. 
generally one of opposition to torture, on the basis that liberal norms, enshrined in domestic and international law, prohibit its use. ${ }^{6}$ Authoritarian states that use torture tend not to claim to oppose it. When they admit its use, they justify it in relation to security. When liberal states do advocate torture, or when they redefine it as something other than torture, they too justify it on security grounds, unless it has been used without the sanction of the state. In such cases its perpetrators are labelled 'bad apples', and in need of better training. This was precisely the conclusion of the initial investigation into torture by US military and intelligence personnel at Abu Ghraib. ${ }^{7}$ Similarly, following the massacre of Iraqis by US troops in Haditha in June 2006, US troops were ordered to take a crash course in battlefield ethics. ${ }^{8}$

The article first of all sets out why torture is assumed to be effective. The three models, referred to as the security, stability and legitimacy models, are then developed. This entails analysing who uses torture in each case and for what purposes, and assessing the degree to which torture effectively serves the intended purposes. In the course of developing the models, the article argues that while it is plausible that torture may sometimes be effective for securing credible intelligence, most torture has very little to do with intelligence. Rather, it serves as a tool to deter political opposition in authoritarian states in order to protect the interests of elites. Despite the assumption that torture tends not to be used by liberal states, the reality is that liberal states do use torture through transnational networks of terror that they establish in collaboration with elites in authoritarian states, in the interests of their own and global elites. In these cases torture is not intended to secure intelligence, but to thwart political opposition that would threaten transnational elite interests. In addition, efforts to secure the right to use torture by liberal elites, as part of these networks of terror, have as much to do with securing the identities of themselves and of their enemies, as with securing the right to use torture against those enemies. The article concludes that torture should be renounced. This is because while torture may sometimes be effective for securing intelligence, the costs of its use are far too high. While torture is also effective for securing stability for elites, this constitutes an illegitimate form of stability, secured through repression, so on this basis, torture should also be condemned. Finally, legitimacy should not be secured through the right to use torture. This should be eschewed and other means of legitimisation should be found.

${ }^{6}$ In the UK, articles of the Council of Europe's 'Convention for the Protection of Human Rights and Fundamental Freedoms' including the prohibition of torture, have been written into the Human Rights Act 1998, See 'Human Rights Act', UK Parliament, 1998, 〈http://www.opsi.gov.uk/ACTS/ acts1998/19980042.htm >. In the US, under Section 2340A of Title 18 of the US Code, torture is prohibited: see 'US Code, 2000 Edition: Title 18 - Crimes and Criminal Procedure, Part I, Crimes: Chapter 113C, Torture, Section 2340A', US Congress, 6 January 2003, 〈http://frwebgate. access.gpo.gov/cgi-bin/getdoc.cgi?dbname = browse_usc\&docid=Cite: +18 USC2340A $\rangle$. International laws include Protocol II, Part II, Article 4, of the Geneva Conventions of 12 August 1949, and relating to the Protection of Victims of non-International Armed Conflicts (Protocol II)', International Committee of the Red Cross, 8 June 1977, 〈http://www.icrc.org/ihl.nsf/ 52d68d14de6160e0c12563da005fdb1b/d67c3971bcff1c10c125641e0052b545?OpenDocument $\rangle$; United Nations, 'Convention Against Torture and Other Cruel, Inhuman or Degrading Treatment or Punishment', United Nations, 1985, 〈http://www.hrweb.org/legal/cat.html〉.

7 Major General Antonio Taguba, Article 15-6 Investigation of the 800th Military Police Brigade (Washington, DC: US Department of Defence, 2004), p. 37.

8 Julian Borger, 'US Troops Ordered to Undergo Ethical Training after Killing of Iraqi Civilians', The Guardian, 2 June 2006, 〈http://www.guardian.co.uk/print/0,,329495232-103550,00.html〉. 


\section{Why is torture considered effective?}

The horribleness of torture is what makes it appear to lend itself to the acquisition of intelligence, the deterring of potential and actual political opposition, and the securing of legitimacy. All manner of torture methods are currently used, including beatings, electric shock, rape, acts which resemble drowning and suffocation, burning with fire and chemicals, sensory deprivation, the witness of the torture of others, especially loved ones, and threats of the same, and sham executions. ${ }^{9}$ Those who justify torture for intelligence assume it works because of its effects on victims. It is believed victims will respond to torture because they would rather speak up than suffer the physical and psychological torment involved. Who would be able to withstand it rather than give the interrogators the information they seek?

Similarly, when used to maintain stability in the interests of elites, it is the characteristics of torture that result in the assumption that it will work. Who would be able to continue to oppose the authorities when faced with torture? Torture against specific political opponents serves an important exemplary function, and is considered effective because of the fear it instils in others. Likewise, when it is used indiscriminately, it is intended to instil fear and curtail political opposition among victims and the rest of society. Torture is assumed to work for both security and stability reasons because people are assumed to have limited thresholds for enduring this kind of abuse - even the toughest of characters will eventually crack, because what is inflicted is so terrible.

Torture also appears to lend itself as a tool for securing legitimacy because its horribleness makes it aberrant. In liberal states, therefore, special circumstances have to attend its use. Firstly, the state determines when certain exceptional conditions are met in which torture can be used. Outside of those conditions the torture would be deemed illegitimate. The ability to determine that such conditions are met depends on securing the legitimacy of the state, based on its liberal credentials, and on the threats that it deems are posed by illiberal actors. Securing that legitimacy, as I will later show, requires the assignment and securing of specific identities to the various actors involved. Secondly, only specific individuals sanctioned by the state can carry out the torture, again because of its exceptional nature. Those who torture without such sanction are considered 'bad apples'. It is the fact that torture is exceptional, therefore, because of its horribleness, that torture is seen to lend itself to processes of legitimisation.

In developing each of the models that account for torture, I will show in more detail how those who justify torture base their arguments on the above assumptions about its effectiveness for each of the purposes it is intended to serve. Beginning with the security model, I will outline who uses torture in the name of security, and the arguments that are used to justify its use, before discussing the degree to which torture is effective to this end.

9 For a full account of modern torture see Peters, Torture, pp. 165-75. His work continues to be one of the most comprehensive accounts. 


\section{The security model}

\section{Who uses torture for reasons of security?}

The dominant model sees torture as a tool that may increase security against threats. The classic argument is that if the arrested terrorist does not talk, hundreds of innocent people will die when the ticking bomb goes off - the 'ticking bomb' argument. For instance, in 1988 an Israeli delegation appeared before the UN Committee Against Torture, which charged Israel with violating the UN Convention Against Torture through its use of what the Israelis refer to as 'moderate pressure' against Palestinians. The delegation defended its tactics, stating:

No one will ever know where and when the next suicide bomb is going to strike, and sometimes we're in special situations where we need to get vital information from a terrorist or a potential terrorist in order to prevent a further act of terror. ${ }^{10}$

Similar arguments are made to justify torture in the 'War on Terror', to obtain intelligence about imminent threats and the activities of other terrorists. The argument is that if the detained terrorist does not talk, another terrorist will plant or explode another bomb, which I refer to as the 'ticking terrorist' argument. As I will later show, President Bush has had this in mind when he has spoken of the 'War on Terror'.

Senior US officials have made the ticking terrorist argument to justify torture in the 'War on Terror'. It has also been the basis for efforts to redefine torture so that only the most extreme forms of physical pain be defined as such. ${ }^{11}$ In the same memo that discussed redefinitions of torture, prepared by the US Justice Department's Office of Legal Counsel, and sent to Alberto Gonzales, counsel to the President in 2002, Jay Bybee advised that torture may be justified to prevent terrorist attacks:

In the current circumstances, however, an enemy combatant in detention does not himself present a threat of harm [.. .] Nonetheless, leading scholarly commentators believe that interrogation of such individuals using methods that might violate Section 2340A [of title 18 of the US Code, which implements the UN's Convention Against Torture] would be justified under the doctrine of self-defence, because the combatant by aiding and promoting the terrorist plot 'has culpably caused the situation where someone might get hurt. If hurting him is the only means to prevent the death or injury of others put at risk by his actions, such torture should be permissible, and on the same basis that self-defence is permissible.' ${ }^{\prime 2}$

There is no discussion of whether torture is effective for securing intelligence, nor of its likely consequences. It is simply assumed torture might be successful in preventing terrorism. Following criticism of the Bybee memo, however, the Department of Justice issued a new memo in December 2004, stating that it 'supersedes the August 2002 memo in its entirety', and that, 'Torture is abhorrent both to American law and

10 BBC, 'Israel Defends Torture in Interrogation Methods', BBC, 15 May 1998, 〈http://users.westnet. gr/ $\sim$ cgian/israelto.htm $\rangle$.

11 Jay Bybee, 'Memorandum for Alberto R. Gonzales, Counsel to the President. Re: Standards of Conduct for Interrogation under 18 USC 2340-2340A (US Department of Justice, Office of Legal Counsel)', in Karen Greenberg and Joshua Dratel (eds.), The Torture Papers: The Road to Abu Ghraib (Cambridge: Cambridge University Press, 1 August 2002), pp. 172-214.

12 Bybee, 'Memorandum for Alberto R. Gonzales', p. 211. 
values and to international norms'. ${ }^{13}$ While the new memo did not directly address the earlier conclusions that torture might be justified on self-defence grounds, this declaration is clear that the US state officially prohibits torture.

The security model has also been invoked in defence of detention facilities such as Guantanamo Bay in the 'War on Terror'. Those detained are portrayed as having information about ticking terrorists, terrorist networks and potential threats that must be mined through interrogation, or 'enhanced interrogation techniques' - the latest euphemism for interrogation involving torture. ${ }^{14}$ Various techniques constituting torture were recommended for use in 2003 by a working group headed by Donald Rumsfeld. They included hooding; dietary and environmental manipulation, including extremes of temperature or introducing unpleasant smells; the adjustment of sleeping times; threat of transfer to a country that the detainee is likely to fear would subject them to torture or death; forced shaving of hair or beard; prolonged standing, but not for more than four hours in a 24 hour period; sleep deprivation, allowing individuals to rest briefly but repeatedly waking them, but not for longer than four days in succession; forced nudity, with no time limit placed on this; increasing anxiety through the presence of a dog without directly threatening action. ${ }^{15}$ Threats of torture are a form of mental torture which is prohibited under Article 75 of Protocol I additional to the Geneva Conventions. ${ }^{16}$

Officials in the US and UK have claimed that torture may have played a role in securing intelligence in relation to terrorism. Republican Senator Kit Bond, a member of the Senate Intelligence Committee, stated that 'enhanced interrogation techniques' had worked with at least one captured Al Qa'ida operative, Khalid Shaikh Mommaded, to thwart an unspecified plot. ${ }^{17}$ Eliza Manningham-Buller, head of MI5, claimed that intelligence acquired from detainees overseas is used by British security and police forces, and that the information obtained 'can be accurate and may enable lives to be saved.' 18 To support her argument, she referred to the case of Mohammed Meguerba who was interrogated by Algerian security personnel, known to regularly use torture, as the US State Department's annual human rights report for 2004 indicates. ${ }^{19}$ Manningham-Buller stated that the Algerian liaison passed on information obtained from Maguerba when under interrogation at the hands of

13 Daniel Levin, 'Memorandum for James B. Comey, Deputy Attorney General, from Daniel Levin, Acting Assistant Attorney General, Re: Legal Standards Applicable Under 18 USC, 2340-2340A', Office of Legal Counsel, US Department of Justice, 30 December 2004, 〈http://www.usdoj.gov/olc/ dagmemo.pdf $\rangle$.

14 Agence France-Presse, 'White House Declines to Totally Rule Out Torture', Agence France-Presse, 13 November 2005, 〈http://news.yahoo.com/s/afp/usattackstorture〉.

15 Donald Rumsfeld, Working Group Report on Detainee Interrogations in the Global War on Terrorism: Assessment of Legal, Historical, Policy and Operational Considerations (Washington DC: Office of the Secretary of Defence, 4 April 2003), in Greenberg and Dratel, The Torture Papers: The Road to Abu Ghraib, pp. 341-4.

16 International Committee of the Red Cross, 'Protocol Additional to the Geneva Conventions of 12 August 1949, and relating to the Protection of Victims of International Armed Conflicts (Protocol I).' International Committee of the Red Cross, 8 June 1977, 〈http://www.icrc.org/ihl.nsf/ 52d68d14de6160e0c12563da005fdb1b/f6c8b9fee14a77fdc125641e0052b079?OpenDocument $\rangle$.

17 Agence France-Presse, 'White House Declines to Totally Rule Out Torture'.

18 Eliza Manningham-Buller, 'Statement of Eliza Manningham-Buller on behalf of the Secretary of State for the Home Department in the House of Lords on Appeal from Her Majesty's Court of Appeal in the case of Mohammed Meguerba', The Security Service, Thames House, obtained by Channel 4 News, 2005, 〈http://www.channel4.com/news/media/2005/10/week_3/20_mi5.pdf $\rangle$.

19 US Department of State, 'Country Reports on Human Rights Practices - 2004: Algeria', US Department of State, 2005, 〈http://www.state.gov/g/drl/rls/hrrpt/2004/41718.htm〉. 
Algerian security personnel, which detailed 'a plot to use a fatal poison in London within the next few days. ${ }^{20}$ One of those behind these supposed attempts to produce explosives and poisons, Bourgass, was convicted for murdering a police officer in a raid, and for 'conspiracy to cause public nuisance', but the jury was dismissed after failing to reach a verdict on the second count against Bourgass: conspiracy to commit murder. The Crown Prosecution Service abandoned plans to re-try Bourgass on the latter charge. ${ }^{21}$ Manningham-Buller asserts that no inquiries were made into the circumstances that attended Algerian questioning of Meguerba, but argues that acting on this intelligence was justified given the need to protect life. ${ }^{22}$ The level of threat posed is called into question by the failure of the jury to determine whether Bourgass did conspire to commit murder, and by the Crown Prosecution Service's decision not to re-try him on this count.

\section{Does torture for security work?}

The assumption that torture is effective for gathering intelligence underpins arguments to legalise torture. Alan Dershowitz, a Harvard law professor, recently deployed the ticking bomb argument in an opinion piece in the Los Angeles Times, posing the question, 'Would torturing one guilty terrorist to prevent the deaths of a thousand innocent civilians shock the conscience of all decent people?' He states, 'if an actual ticking bomb situation were to arise, our law enforcement authorities would torture' and on this basis, 'The real debate is whether such torture should take place outside of our legal system or within it'. His response is, 'If we are to have torture, it should be authorized by the law'. ${ }^{23} \mathrm{He}$ thus calls for legislation which would permit torture in specific security-related scenarios.

While it is plausible that torture may yield credible intelligence, we cannot conclude with any confidence that this is the usual outcome when torture is used to secure intelligence. Similarly, we should not assume that torture is effective to this end just because those with a specific interest in justifying torture claim that it works. For instance, the Israeli Defence Forces have frequently claimed that torture is effective, including in the case of Nachshon Waxman, an Israeli corporal kidnapped by Palestinians in 1994. The Israelis captured the driver of the car used in the kidnapping, and Yitzhak Rabin, then prime minister, later admitted they had tortured beyond the guidelines for coercive interrogation, but that the driver talked, the information was accurate and Waxman was found. ${ }^{24}$ Joseph Lelyveld, a New York Times journalist investigating torture, was repeatedly told by Israeli officials, that 'coercive interrogation had effectively thwarted missions of would-be suicide

${ }^{20}$ Manningham-Buller, 'Statement'.

21 BBC, 'The Ricin Case Timeline', BBC, 13 April 2005, 〈http://news.bbc.co.uk/2/hi/uk_news/ 4433459.stm >.

22 Manningham-Buller, 'Statement'.

23 Alan Dershowitz, 'Is There a Torturous Road to Justice?' Los Angeles Times, 8 November 2001, p. 19.

24 Charles Krauthammer, 'The Truth About Torture', The Weekly Standard, 5 December 2005, 〈http://www.weeklystandard.com/Content/Public/Articles/000/000/006/400rhqav.asp $\rangle.$ 
bombers, saving lives'. ${ }^{25}$ Similarly, in the 'War on Terror', CIA sources recently stated that Khalid Sheikh Mohammed, a high profile detainee in the 'War on Terror', was subjected to water-boarding, a technique similar to drowning, and was able to last two and a half minutes before begging to confess to being the architect behind the 9/11 attacks, and providing information on an unspecified terrorist plot. ${ }^{26}$ In each of these cases it may be true that torture did lead to credible intelligence, but we cannot be confident this was the case, nor whether this is frequently the case. Neither can we be confident that torture was the only means by which the information could have been acquired. There is certainly no strong evidence that points to the widespread utility of torture for this purpose. Furthermore, officials who claim torture has worked in this way never mention cases in which torture has resulted in false confessions or fabricated intelligence, even though there is ample evidence to show that victims of torture will say anything to halt the torture.

Information or confessions secured under torture are likely to be unreliable, as victims will say or do anything to make the torture stop. This was the argument made by liberals in the 1760 s and 1770 s as they tried to end the use of torture which had been practised widely in pre-Enlightenment Europe as a tool for securing confessions. As Cesare Beccaria, an Italian political philosopher argued:

[T] he impression made by pain may grow to such an extent that having filled the whole of the sensory field, it leaves the torture victim no freedom to do anything but choose the quickest route to relieving himself of the immediate pain. ${ }^{27}$

US Senator John McCain confirms that in his own experience of torture in Vietnam, he 'provided them with false information' which he thought would be 'sufficient to suspend the abuse'. ${ }^{28}$ Similarly, in testimony gathered by Human Rights Watch, an Israeli sergeant spoke of his reserve duty in 1989 with the Israeli Defence Force (IDF) at the interrogation unit of the Al-Fara'a detention centre. He described the torture, stating that it included beating which led to the breaking of bones and pouring acid onto the Palestinian detainees. When asked whether the confessions signed were false, he stated, 'I don't really know, I don't speak Arabic. But believe me, they would sign anything towards the end, no matter whether they did it or not. Anything. ${ }^{29}$ While it is plausible that torture might result in credible intelligence, it is far more likely to result in false confessions and false intelligence, because victims, faced with the horror of torture, are likely to say anything that will make the torture stop. Indeed, torture is highly effective for securing false information. Despite this, justifications for torture have been made on the basis of its presumed utility for acquiring accurate intelligence, as in the case of Dershowitz, who argues for torture warrants that would permit its use in specific circumstances. ${ }^{30}$

25 Joseph Lelyveld, 'Interrogating Ourselves', New York Times Sunday Magazine, 12 June 2005, $\langle$ http://www.refuseandresist.org/detentions/art.php?aid=2059〉; Agence France-Presse, 'White House Declines to Totally Rule Out Torture'.

${ }^{26}$ Krauthammer, 'The Truth About Torture'.

27 Beccaria, On Crimes and Punishments, p. 41.

28 John McCain, 'Torture's Terrible Toll: Abusive Interrogation Tactics Produce Bad Intel, and Undermine the Values We Hold Dear. Why We Must, As A Nation, Do Better,' Newsweek, November 2005, 〈http://www.msnbc.msn.com/id/10019179/site/newsweek/〉.

29 Human Rights Watch, Torture and Ill-Treatment: Israel's Interrogation of Palestinians from the Occupied Territories (New York: Human Rights Watch, 1994), Appendix F, Testimony of Sergeant A.M, pp. 305-11.

30 Dershowitz, 'Is There a Torturous Road to Justice?' 
To justify torture on security grounds one has to make three highly dubious assumptions. The first of these is that torture is effective for securing intelligence, which is far from proven. Indeed there are good grounds for believing the opposite to be true, namely, that torture is likely to result in the acquisition of false confessions and intelligence. Secondly, if torture is permitted in order to secure intelligence, torture is somehow legitimate, even though its victims may well be innocent. Finally, the primary function of torture is to defeat security threats. As I will now show, most torture has little to do with protecting populations from imminent security threats, and far more to do with overcoming threats to the interests of transnational elite groups.

\section{The stability model}

\section{Who uses torture for reasons of stability?}

The stability model sees torture as a tool of state terror to discipline the population and suppress potential or actual political opposition that would pose a threat to the interests of elites. ${ }^{31}$ Such opposition includes revolutionary and insurgent movements, but frequently also includes opposition parties, trade unions, groups calling for democracy or for political freedoms, as well as anyone suspected of potentially being associated with such groups, either now or in the future. ${ }^{32}$ Frequently torture starts out as a tool to be used against specific individuals or groups in order to make an example of those who dare to challenge the regime, and to instil in others compliance, out of fear. The torture is publicised through state-controlled media coverage, or word of mouth, otherwise it would fail to serve a deterrent purpose. ${ }^{33}$ For example, Amnesty International reported that in Guatemala during the 1980s, newspapers were permitted to publish photographs of dead torture victims:

Guatemalan counterinsurgency operations in the early 1980s [. . . included the terrorisation of targeted rural populations in an effort to ensure that they did not provide support for guerrillas. Tortured, dying villagers were displayed to relatives and neighbours who were prevented from helping them. Newspapers in urban areas during this period were allowed to publish photographs of mutilated bodies, ostensibly as an aid to families seeking their missing relatives, but also as a warning to all citizens not to oppose the government. ${ }^{34}$

Rarely does torture remain a tool to be used against specific individuals and opposition groups, however. It tends to spiral out of control, so that the torture becomes widespread and indiscriminate. This is because, while torture may initially be intended for use against overt political opponents, those in control of torture regimes tend to be poor at finding such opponents, and at distinguishing between

31 Chomsky and Herman, The Washington Connection and Third World Fascism, pp. 1-40; Gabriel Kolko, Confronting the Third World: United States Foreign Policy 1945-1980 (New York: Pantheon Books, 1988), pp. 3-16; Doug Stokes, America's Other War (London: Zed Books, 2005), pp. 18-34; 'Why the End of the Cold War Doesn't Matter: the US War of Terror in Colombia', Review of International Studies, 29:4 (2003), pp. 560-85.

32 Some revolutionary and insurgent movements may also be considered legitimate if their cause is to overthrow illegitimate, repressive regimes.

33 Rejali, 'How Not to Talk About Torture', p. 129.

34 Amnesty International, Briefing, Guatemala (London: Amnesty International, 1976), p. 5. 
those and others that pose little or no threat. One tactic deployed is to detain and torture the associates of known opponents, initially close friends and family, but before long large networks of people who have had only fleeting contact with suspected opponents. Simultaneously, notions of what constitutes political opponents are widely interpreted, so that before long, all kinds of people are considered a threat. For example, teachers who may not be at all interested in political processes are considered a threat because they are classified as individuals who may be interested in politics and may at some point get involved in opposition groups, and because they may yield influence over others. Similarly, students may be considered a threat because they spend time thinking and engaging with others and are in a good position to organise. They too may therefore face threats of torture.

Once torture reaches such levels, it is usually accompanied by mass murder and detention. Again, this is intended to instil fear across the whole of society to deter opposition, and is intended to literally eliminate potential and actual opposition. Torture of this kind occurred under the 'Reign of Terror' during the French Revolution; in Stalinist Russia; under the Nazis; in Communist China; by the British against suspected communists in internment camps in Germany following World War II; ${ }^{35}$ under the US-backed military governments embroiled in counterinsurgency campaigns across Latin America during the Cold War; ${ }^{36}$ under the Phoenix Program led by US military and intelligence services in Vietnam;37 and now in Iraq under the Shia militia-controlled Ministry of the Interior. ${ }^{38}$

In the Latin American cases torture was at first used against specific political opponents. In Colombia in the 1960s and in Argentina and Chile in the 1970s and 1980s, torture was routinely practised under the military governments against political prisoners at multiple detention centres, as many as 60 of which were in operation in Argentina and 33 in Colombia. ${ }^{39}$ Before long the torture spread and was used indiscriminately across society. For example, initially the victims of the military government in Chile which had overthrown Salvador Allende in 1973 were Allende's supporters, who were arrested, tortured and assassinated. Within a year of the coup up to 30,000 people were murdered, and many of those tortured. ${ }^{40}$ Within the first two years of the coup, over 40,000 people had been detained for periods longer than 24 hours, some for weeks or months, and approximately 140,000 were held briefly for intimidation purposes. ${ }^{41}$ Three years into the regime most people considered to be adversaries, whether Allende supporters or not, were the victims of torture or assassination, or were in exile. ${ }^{42}$

Those who advocate torture on security grounds tend not to engage with the realities of its use - that it is for the most part a tool for deterring potential and actual

35 Ian Cobain, 'The Postwar Photographs that British Authorities Tried to Keep Hidden', The Guardian, 3 April 2006, 〈http://www.guardian.co.uk/germany/article/0,,1745662,00.html〉.

36 Herman, The Real Terror Network.

37 Valentine, The Phoenix Program.

38 Human Rights Watch, 'The New Iraq? Torture and Ill-Treatment of Detainees in Iraqi Custody', Human Rights Watch, January 2005, 〈http://hrw.org/reports/2005/iraq0105/index.htm〉.

39 Ibid., pp. 2, 112-14.

40 Ibid., p. 54.

41 United Nations, Ad Hoc Working Group on Human Rights in Chile, Report of the Economic and Social Council (A/10285) (New York: United Nations, 1975), p. 74.

42 Cynthia Brown, With Friends Like These: The Americas Watch Report on Human Rights and US Policy in Latin America (New York: Pantheon Books, 1985), p. 47. 
opposition. They even assume that it can be controlled. Dershowitz, for example, assumes that by regulating torture in the US for security purposes, we can avoid 'expand[ing] its use'. ${ }^{43}$ Within liberal democratic states this may be possible, because, as I will show, liberal states tend to have other means of ensuring that the interests of elites are protected. Nevertheless, securing the right to use torture and regulating its use within liberal states, as Dershowitz proposes, will have little effect on torture when it is used to ensure stability for elites within authoritarian states, other than to help legitimise it. Neither will it affect torture as practised by transnational networks of elites, including those from liberal states, that collaborate in its use, as I will show. Indeed, as the above cases indicate, and as Amnesty International point out, in all the decades that they have researched torture, it always expands from a few isolated cases to being widespread and fairly indiscriminate:

We have not found a single state which tortures 'only once', or only in a few extreme cases. Whenever and wherever torture and cruelty are accepted as legitimate tools of government 'in extreme circumstances' they become widespread - the means used become increasingly extreme and the circumstances in which they are used increasingly less so. Moreover, those states which use torture and ill-treatment against political opponents do not stop at these acts, but resort also to other violent and repressive measures, such as 'disappearances' and extrajudicial executions, not only against detainees, but also against a wider population associated with the 'enemy'. ${ }^{44}$

Thus regulating torture within the confines of liberal states, as Dershowitz proposes for the US, will have no effect upon the torture that is used by authoritarian states, and by transnational elites, including from liberal states, against thousands to curtail threats to elite interests.

It tends to be assumed that only authoritarian states engage in the widespread use of torture to ensure stability for the elite, and that liberal states do not. The reality is that torture tends not to be used domestically in liberal states for stability purposes, but their use of torture is usually located in the South. Elites from liberal states have colluded with elites in the South in the institution of networks to deter political opposition through repression, including torture, and to quash movements that pose a threat to elite interests. This tends to be absent from mainstream accounts of terror and torture, which is partly a consequence of the sovereign state-centric logic of IR. As Tarak Barkawi and Mark Laffey note, within IR "the "international" is a "thin" space of strategic interaction, populated by diplomats, soldiers and capitalists". ${ }^{45}$ As a result, the centuries-long global character of world politics, which comprises transnational networks of cooperation for a variety of purposes, including terror and torture, is obscured. ${ }^{46}$ If we reconfigure our notion of the international along these lines, however, we have a much richer understanding of the complex or 'thick' set of social relations consisting of political-military, social and cultural flows, as well as economic interactions, that have shaped world politics. The distinction between liberal and authoritarian states in relation to torture is diminished when we understand these interconnections by reference to an international state, dominated

43 Dershowitz, 'Is There a Torturous Road to Justice?'

44 Amnesty International, 'Torture and Ill-Treatment: The Arguments', Amnesty International, 2006, 〈http://web.amnesty.org/pages/stoptorture-arguments-eng $\rangle$.

45 Tarak Barkawi and Mark Laffey, 'Retrieving the Imperial: Empire and International Relations', Millennium, 31:1 (2002), p. 110.

46 Barkawi and Laffey, 'Retrieving the Imperial', p. 110. 
since World War II by the US. Since World War II a hierarchy, with the US at the apex, has come into being through the proliferation of transnational institutions and arrangements that are primarily intended to serve the interests of the US state and its capitalist elites, but which also serves the interests of other core capitalists states, and global capitalist elites. ${ }^{47}$ As I will show, one such arrangement established between the US and various allies in the Cold War consisted of a terror network in which torture was widespread and was intended to thwart movements that posed a threat to local and US elite interests in the South. I refer to a terror rather than a torture network because torture is just one of a number of repressive tools that collaborating elites use to subdue and defeat threats to their interests.

Before discussing those terror networks that existed in the Cold War, I will first explain why liberal democratic states tend not to use torture domestically to ensure stability for elites. The aim of elites in liberal democratic states is to establish consent through the political and ideological incorporation of subordinate groups within civil society. ${ }^{48}$ Liberal democracy constitutes a system in which a small group rules and mass participation in decision-making is confined to a leadership choice in elections, carefully managed by competing elites, although not always successfully. ${ }^{49}$ So, while liberal democracy is preferable to authoritarian systems of government, it should be noted that both are deliberately intended to serve the interests of elites. This is achieved through the establishment of a system stable for those elites, because subordinate classes are granted some freedoms and choices, but only to the point that the system itself remains intact, and that ultimately will benefit elites. ${ }^{50}$ Because of this, liberal states do not need to resort to torture.

In contrast, in authoritarian states, political opposition is frequently managed through the curtailment of freedoms. The work by Zeev Maoz and Bruce Russett is instructive here. ${ }^{51}$ They argue:

International action in a democratic political system requires the mobilisation of both general public opinion and of a variety of institutions that make up the system of government, such as the legislature, the political bureaucracies, and key interest groups [...] On the other hand, in nondemocratic societies, once the support of the key legitimising groups is secured, the government can launch its policy with little regard for public opinion or for due political process. ${ }^{52}$

The use of torture would similarly require the mobilisation of public opinion and of various institutions, particularly as this would be a derogation from liberal norms. This helps explain the lengths that US officials have gone to in the 'War on Terror' to legitimise torture, although they do not call it torture and insist that it is not torture. In authoritarian states, public opinion and due political process do not

47 Ibid., pp. 124-5; Peter Gowan, The Global Gamble; Washington's Faustian Bid for World Dominance (London: Verso, 1999); Doug Stokes, 'The Heart of Empire? Theorising US Empire In An Era Of Transnational Globalisation', Third World Quarterly, 26:2 (2005), pp. 217-36; William Robinson, Promoting Polyarchy: Globalisation, US Intervention, and Hegemony (Cambridge: Cambridge University Press, 1996).

48 Robinson, Promoting Polyarchy, p. 24.

49 Ibid., p. 49.

50 Poulantzas, Political Power and Social Classes, pp. 130-91.

51 Zeev Maoz and Bruce Russett, 'Normative and Structural Causes of Democratic Peace, 1946-1986', American Political Science Review, 87:3 (1993), pp. 624-38.

52 Ibid., p. 626. 
feature in the same way in decision-making. Other methods are used to ensure cooperation of subordinate groups, including torture.

The distinction between liberal and authoritarian states with regard to torture, however, is less sharp than it might at first appear. Elites in liberal states have used torture in collaboration with elites in the South as part of transnational terror networks. One example is the collaboration between the US and various Latin American states during the Cold War. The notion that repression including torture would help bring about stability underpinned US rationale for supporting torturing regimes in the Third World. The US argued that curtailing political opposition in this way would, in the long run, result in the establishment of democracy. Jeanne Kirkpatrick, US Ambassador to the UN in the Reagan administration, acknowledged that authoritarian regimes 'sometimes invoked martial law to arrest, imprison, exile, and occasionally, it was alleged, torture their opponents'. ${ }^{3}$ She argued, however, that it might be necessary to support them: 'Since many traditional autocracies permit limited contestation and participation, it is not impossible that US policy could effectively encourage this process of liberalisation and democratisation'. ${ }^{54}$

States in Latin America where the US sponsored torture during the Cold War are now liberal democracies. However, while Kirkpatrick was correct about the outcome, her reasons for that outcome were incorrect as I will show. Kirkpatrick distinguished between authoritarian regimes which she saw as potentially attentive to processes of liberalisation and democratisation, and what she referred to as revolutionary Communist regimes:

Generally speaking, traditional autocrats tolerate social inequalities, brutality and poverty, while revolutionary autocracies create them. Traditional autocrats leave in place existing allocations of wealth, power, status ... they do not disturb habitual rhythms of work and leisure, habitual places of residence, habitual patterns of family and personal relationships ... Precisely the opposite is true of revolutionary Communist regimes. ${ }^{55}$

Revolutionary communist governments do have a history of brutality, but the idea that autocratic regimes 'tolerate' rather than 'create' it is simply untrue. As the case of Chile shows, traditional autocrats such as Pinochet did create thousands of exiles because of the repression he unleashed. Pinochet also returned properties that had previously been expropriated by the social democratic government of Allende to their former owners. This included US corporations, all of which reclaimed their investments. ${ }^{56}$ Thus existing allocations of wealth and power were disturbed by Pinochet, the traditional autocrat. It just happens that this was in the interests of US elites. Furthermore, whereas Kirkpatrick referred specifically to revolutionary communist regimes, US policies stemming from her arguments consisted not simply of acting against brutal revolutionary communist regimes, but advocating repression against entirely legitimate groups on the left.

US support for counterinsurgency efforts against left-wing movements in Latin America included military training which advocated repression, including torture, not simply against brutal revolutionary communists, but indiscriminately across

\footnotetext{
53 Jeanne Kirkpatrick, 'Dictators and Double Standards', Commentary, 68:5 (1979), pp. 34-5.

54 Ibid., p. 44.

55 Ibid.

56 Robinson, Promoting Polyarchy, p. 165.
} 
society. ${ }^{57}$ For example, a US training manual entitled Handling Sources, was one of several manuals used to train Latin American military personnel at the School of the Americas, and which included material that advocated infiltration of all types of legitimate social organisation, including youth groups, trade unions, and political parties, and using fear and revenge to recruit counterintelligence agents. ${ }^{58}$ When coupled with the material in these manuals that advocated torturing suspected opponents of the regime, we see that the US backed this kind of indiscriminate repression.

Complicity in and advocacy of repression, including torture, was not limited to US training of Latin American military personnel. The intelligence agencies and militaries of the US and various Latin American states cooperated in gathering and sharing information about people involved in legitimate social organisations across the whole of society, not simply those involved in insurgencies. Throughout the period, the US was involved with the Chilean secret police (DINA), and security agencies of other Southern Cone states, including Argentina, Bolivia, Brazil, Paraguay and Uruguay, in a programme known as Operation Condor. This was operative by 1975 and built on pre-existing arrangements for sharing intelligence and close cooperation between the US and Latin American allies, all of which were already embroiled in repression before the US came on board with them. ${ }^{59}$ A now declassified cable written by Robert Scherrer, the FBI's attaché in Buenos Aires, describes Operation Condor as a joint intelligence operation that was intended to 'eliminate Marxist terrorist activities in the area', and indicates that Chile was the centre of the operation:

Operation Condor involves the formation of special teams from member countries who are to travel anywhere in the world to non-member countries to carry out sanctions up to assassination against terrorists or supporters of terrorist organisations from 'Operation Condor' member countries. ${ }^{60}$

Thus the US sanctioned the assassination of political opponents abroad, to accompany the ongoing human rights abuses that the Chilean and other Latin American governments were committing at home.

Just as the case of torture in Latin America during the Cold War is indicative of an international terror network, under the leadership of the US, so too is the policy of extraordinary rendition in the 'War on Terror'. This policy, headed by the US but implicating numerous allies, involves the transfer of suspects to third-party states

57 Central Intelligence Agency, Kubark Counterintelligence Interrogation (Washington, DC: Central Intelligence Agency, 1963, Manual acquired by National Security Archives, under the Freedom of Information Act); US Department of Defence, Field Manual 30-5: Combat Intelligence (Washington, DC: US Department of Defence: Army, 1973); 'School of the Americas Training Manual: Handling Sources', US Department of Defence, 1989, 〈http://www.soaw.org $\rangle$. For an analysis of the manuals see Lisa Haugaard, 'Declassified Army and Central Intelligence Agency Manuals Used in Latin America: An Analysis of their Content', Latin American Working Group, 18 February 1997, 〈http://www.lawg.org/pages/new\%20pages/Misc/Publications-manuals.htm $\rangle$.

58 Handling Sources, pp. 1-37 and p. 128.

59 Michael McClintock, 'The United States and Operation Condor: Military Doctrine in an Unconventional War' (paper presented at the Latin American Studies Association Conference, Washington DC, September 2001), p. 3.

${ }^{60}$ Robert Scherrer, 'Operation Condor Cable, 28 September 1976', FBI, 28 September 1976 (Declassified document, obtained by the National Security Archive, George Washington University, Washington DC, NSA Electronic Briefing Book 8), (http://www.gwu.edu/ nsarchiv/NSAEBB/ NSAEBB8/ch23-01.htm〉. 
where torture is commonplace. ${ }^{61}$ Fourteen EU states have been involved in US rendition programmes, at the very least by knowing what was going on, and in the case of the UK, by handing over information about its residents and former residents that has allegedly led to renditions and torture; in the cases of the UK, Ireland, Portugal and Greece, by providing stopovers for CIA aeroplanes allegedly involved in rendition; in the cases of Spain, Turkey, Germany and Cyprus, by providing staging posts for rendition operations; in the cases of Italy, Sweden, Bosnia and Macedonia, by allowing the rendition of their citizens; and in the cases of Poland and Romania, by allegedly allowing the US to run secret prisons on their territory. ${ }^{62}$ Thus elites in numerous EU states, the US, and states in the South to which terror suspects are rendered, are tied together by a common cause which transcends state boundaries.

\section{Does torture for stability work?}

On the one hand, torture does instil fear within the population and can deter political opposition. This may be because torture is rarely restricted to specific political opponents, but tends to become widespread and fairly indiscriminate. In such circumstances everyone fears that they may be next, which may cause them to avoid any kind of political activity, or associating with others who are politically active, although such avoidance may not be enough to protect them. The fear is compounded when the torture is accompanied by disappearances and murders. In such circumstances, as the case of Chile shows, potential and actual opponents are literally eliminated, either because they are killed or because they flee.

On the other hand, torture itself leads to resistance and increased opposition against the regime. General Jacques Massu, Commander during the French-Algerian war, and one of the main perpetrators of torture, admitted years later that the torture had served no useful or necessary intelligence purpose in overcoming terrorism, but had turned most of the Algerian population against the French, pushing them into the arms of the Front de Libération National. ${ }^{63}$ Likewise, after seven years Pinochet's regime was forced to bring about a transition to democracy, largely as a consequence of mounting unrest within Chile and campaigning abroad, the demise of military regimes in other Latin American states, and a subsequent shift in US support from Pinochet's regime to the elite opposition. ${ }^{64}$ Kirkpatrick's forecast about the outcome of supporting authoritarian regimes was correct in the case of Chile, and other Latin American states: eventually those authoritarian regimes were replaced by democracy. Her explanation was incorrect, however. They withered not because US support for

61 Seymour Hersh, Chain of Command. The Road from 9/11 to Abu Ghraib (London: Penguin Books, 2004); Jane Mayer, 'Outsourcing Torture: The Secret History of America's 'Extraordinary Rendition’ Programme', 7 February 2005, 〈http://www.newyorker.com/printables/fact/ 050214fa_fact6); Dana Priest, 'CIA Holds Terror Suspects in Secret Prisons', Washington Post, 2 November 2005, 〈http://www.washingtonpost.com/wp-dyn/content/article/2005/11/01/ AR2005110101644_pf.html〉; 'Jet is an Open Secret in Terror War', Washington Post, 27 December 2004, 〈http://www.washingtonpost.com/wp-dyn/articles/A27826-2004Dec26.html〉.

62 Stephen Grey and Ian Cobain, 'From Logistics to Turning a Blind Eye: Europe's Role in Terror Abductions', The Guardian, 7 June 2006, 〈http://www.guardian.co.uk/usa/story/0,,1791991,00.html〉.

63 MacMaster, 'Torture: From Algiers to Abu Ghraib', p. 9.

64 Robinson, Promoting Polyarchy, pp. 167-68. 
terror brought about democracy, but because such terror generated sufficient resistance to bring about the overthrow of such regimes.

Where the torture can to some degree be controlled and contained, often by assigning it to a specific ethnic group such as the Kurds under Saddam Hussein, or the Palestinians by the Israelis, however, the regime may be able to sustain its use in the long term, as has been the case with the torture of Palestinians arrested and held by the Israeli Defence Force. It is by no means clear in that case, however, that the use of torture is contributing to the stability of the Israeli government. It may indeed be contributing to increased resistance from Palestinian and other resistance groups in the region. Nevertheless, it may be that the Israeli authorities have succeeded in continuing to use torture because they effectively invoke security arguments to justify their actions. Also, their legitimacy, in light of their use of torture, has not been adequately challenged internationally, partly because of their close relationships with leading Northern states including the US and EU members, which affords them legitimacy. Such appeals to legitimacy are similar to the efforts that individuals within the US are making as they claim the right to torture, on the basis of the legitimacy they enjoy as a liberal state.

\section{The legitimacy model}

\section{Who uses torture for reasons of legitimacy?}

The legitimacy model accounts for the ways in which the right to torture is claimed on the basis of the assignment of specific identities to the actors involved, and how securing the right to torture is also intended to secure those particular identities. It tends to be liberal elites that seek to secure the right to torture and the identities of themselves and their enemies in this way. This is because their claim to the right to torture, and their efforts to secure specific identities, are based on appeals to legitimacy because of their liberal credentials. The identities that they seek to assign provide the basis for their arguments that torture is justified, and that they, or more specifically, individuals especially sanctioned by them, are legitimated to use it. Establishing identities in this way is not a one-time process. Rather it has to be repeated over and over in the face of resistance. The identities only exist in their reassertion, and each time those identities are challenged, they have to be reasserted. The right to torture is claimed in an attempt to secure and fix those identities. It is thus a two-way performative process: on the one hand the claim is made that they are legitimate so they can use torture, and on the other hand, by claiming the right to torture they can present themselves as legitimate because they have secured that right. 65

\footnotetext{
65 The legitimacy model is grounded in the identity politics approach, the main IR proponent of which is David Campbell, see Writing Security: US Foreign Policy and the Politics of Identity (Minneapolis, MN and Manchester: University of Minnesota Press and Manchester University Press, 1998). See also Richard Jackson, Writing the War on Terrorism: Language, Politics and Counter-Terrorism (Manchester: Manchester University Press, 2005); Richard Devetak, 'The Gothic Sense of International Relations: Ghosts, Monsters, Terror and the Sublime after September 11', Review of International Studies, 31:4 (2005), pp. 621-43.
} 
In the 'War on Terror', supposed and actual terrorists are identified as evil enemies, and the US state, its allies, and their security and intelligence forces, as upholders of freedom and peace. Particularly in the US, such rhetoric is permeated with images of good and evil. In his address to the nation following the 9/11 attacks, President Bush declared:

America was targeted for attack because we're the brightest beacon for freedom and opportunity in the world. And no one will keep that light from shining [. . .] Today, our nation saw evil, the very worst of human nature. And we responded with the best of America [...] with the caring for strangers and neighbours [...] We go forward to defend freedom and all that is good and just in our world. ${ }^{66}$

Since 9/11, declarations from Bush have echoed the same sentiments, with actual and suspected terrorists being cast as evil, and the US and its allies as upholders of justice, freedom and peace. In January 2002, Bush stated:

Our cause is just and it continues [. . . Thousands of dangerous killers, schooled in the methods of murder, often supported by outlaw regimes, are now spreading throughout the world like ticking bombs, set to go off without warning [. . .] My hope is that all nations will heed our call, and eliminate the terrorist parasites who threaten their countries or our own. ${ }^{67}$

Similar statements have been made by Tony Blair in response to the terrorist attacks on London in July 2005:

It's important however that those engaged in terrorism realise that our determination to defend our values and our way of life is greater than their determination to cause death and destruction to innocent people in a desire to impose extremism on the world. ${ }^{68}$

The identities of the different actors in the 'War on Terror' are thus constructed. These images of (potential) terrorists as ticking bombs posing an imminent threat to freedom lend themselves to the appeals for legitimacy of those fighting the 'War on Terror'.

Assigning identities in this way provides the basis for efforts by individuals within the Bush administration to secure the right for US agencies to torture. The American upholders of freedom are deemed trustworthy to torture, on the grounds that it is a necessary action on the part of those fighting for freedom, justice and peace against the evil, murdering, parasitical enemy. Those engaging in such efforts to justify torture are trying to establish among society the notion that supposed terrorists are evil, and therefore deserving of torture on the basis of their evilness. Assigning identities in this way is intended to legitimise the use of torture and entrust its use to the state, to be used as it sees fit. Torture will thereby be considered to be safe in their hands, because the prospects of terrorists threatening freedom are presented as far worse.

Just as those identities underpin the claim to legitimacy which then permits the use of torture in specific circumstances, the torture, and the claim to the right to use it, is merely intended to secure the identities of its advocates and other actors. Whether

\footnotetext{
${ }^{66}$ George Bush, 'Address to the Nation', The Oval Office, 11 September 2001, 〈http:// www.whitehouse.gov/news/releases/2001/09/20010911-16.html〉.

${ }^{67}$ George Bush, 'State of the Union Address', 29 January 2002, 〈http://www.whitehouse.gov/news/ releases/2002/01/20020129\%2D11.html .

68 Tony Blair, 'Statement From Gleneagles Following the 7 July Bombings', 7 July 2005, $\langle$ http://news.bbc.co.uk/2/hi/uk_news/4659953.stm〉.
} 
torture works as a means of acquiring accurate intelligence against threats is therefore entirely irrelevant. The purpose is to secure the right to use torture and in so doing to secure the identities of the actors involved. Because the right to torture has been secured, those that have secured that right are therefore legitimate. Torture is a special practice to be used only by especially appointed individuals in special circumstances. Therefore, if the right to use it can be secured, the identities of those seeking to secure that right are also secured, as are those of the individuals against whom the torture will be used. This is not a one-off process however. As soon as those identities are challenged, they have to be reasserted. Similarly, if the right to use torture is challenged, that right has to be reclaimed through the rearticulation of those identities.

Senior officials have called for support for specific groups within the US to be deemed trustworthy to torture. Jamie Wilson reported in 2005 that the White House 'wants the CIA to be exempted from a proposed ban on the abusive treatment of terrorism suspects being held in US custody'. ${ }^{69}$ Wilson describes how, following the passing of legislation by the Senate three weeks previously that would outlaw the cruel, inhuman or degrading treatment of anyone held by the US, anonymous officials informed the New York Times and Washington Post that Dick Cheney, vice-president, "proposed a change so that the law would not apply to counter-terror operations abroad or to operations conducted by "an element" of the US government other than the defence department'. ${ }^{70}$ To have reached the stage where such requests are being made requires that specific identities of the actors involved are recognised and accepted by society.

\section{Does torture for legitimacy work?}

There is evidence to suggest that efforts by liberal states to secure the right to torture may be working, at least among the American population. Associated Press and IPSOS polling carried out in 2005 in nine countries - the US and eight of its allies - found that almost two thirds of Americans support secret interrogations of terror suspects. ${ }^{71}$ Nevertheless, nearly three-quarters of Americans polled by Newsweek believed that America's image abroad had been tarnished by allegations of torture in US detention facilities. ${ }^{72}$ There is therefore an acknowledgement of the fact that complicity in torture does undermine a state's legitimacy internationally, although this does not appear to have affected the dominant view among Americans that torture may be permissible.

While US elites may be succeeding in securing the right to torture at home, their legitimacy is being undermined abroad. This matters because US efforts to secure the right to torture do not merely affect the American population. Rather, because of the collaboration between the US and transnational elites in a network of terror, most

69 Jamie Wilson, 'Bush Seeks CIA Exemption from Ban on Cruelty to Terror Suspects', The Guardian, 26 October 2005, p. 16.

70 Wilson, 'Bush Seeks CIA Exemption', p. 16.

71 Will Lester, 'Poll Shows Divide on Question of Torture', Associated Press, 6 December 2005, $\langle$ http://abcnews.go.com/US/wireStory?id $=1376448 \&$ page $=1\rangle$.

72 Evan Thomas and Michael Hirsh, 'The Debate Over Torture', Newsweek, 21 November 2005, $\langle$ http://www.msnbc.msn.com/id/10020629/site/newsweek/〉. 
obviously manifested by the policy of extraordinary rendition, populations all over the world are affected, and are resisting. Indeed, other populations are, through their opposition to torture, challenging not only US legitimacy, but also the legitimacy of the elites in their own and other states that are implicated in transnational terror networks. Challenges to the legitimacy of the US are born out in polls among other populations. Associated Press and IPSOS found that two-thirds of those living in Canada, Mexico, South Korea and Spain would oppose allowing the US to secretly interrogate terror suspects. Almost two-thirds in Britain, France, Germany and Italy would also oppose it. Whereas only 36 per cent of the Americans polled thought torture could never be justified, half of the British, Canadians, Germans and Spanish thought it could never be justified. Strongest opposition to torture was found among the Italian respondents, 60 per cent of whom said torture could never be justified. ${ }^{73}$ Given that a number of these states are implicated in the US-led extraordinary rendition programme, their own legitimacy is also challenged by the majority in those states who oppose secret interrogation and torture.

Beyond the US there has also been significant criticism of other US policies which violate human rights. Recent surveys show public opinion for the US falling, with Europeans in particular labelling the US the biggest threat to global security. This fall is linked to unpopular US policies, particularly the US-led invasion and occupation of Iraq, but it may be that evidence of torture at the hands of US intelligence and military personnel, as well as evidence of efforts on the part of the US to justify torture, has played some part in the delegitimisation of the US state. ${ }^{74}$

The legitimacy of the US and its allies has not only been undermined among the public of its allies, but also among the Iraqi population, for the most part because of its disastrous invasion and occupation of Iraq. Revelations that torture occurred at Abu Ghraib, and that torture may have been used at other US detention facilities is likely to have contributed further to the delegitimisation of the US among Iraqis. The Bush administration's response to Abu Ghraib was one of condemnation, with Bush stating that Abu Ghraib 'became a symbol of disgraceful conduct by a few American troops who dishonoured our country and disregarded our values.' 75 Nevertheless, it is clear that the administration has been involved in advocating torture, and this did create confusion among US military and intelligence personnel about what was permitted and what was not. Several US Department of Defence personnel indicated in interviews that there was confusion about what was appropriate with regard to interrogation, following the issue of the various memos by the President, the Department of Justice and the Department of Defence itself. ${ }^{76}$ So whereas the administration condemned the Abu Ghraib torture, it cannot deny responsibility for the attitudes that developed as a consequence of efforts to redefine torture. Abu Ghraib was a symptom of a wider set of practices that the US has been using and seeking to use in the 'War on Terror', including secret detention, denying legal

73 Lester, 'Poll Shows Divide on Question of Torture'.

74 Howard LaFranchi, 'US Effort to Rehab Image Falls Short', The Christian Science Monitor, 21 June 2006, 〈http://www.truthout.org/docs_2006/062106K.shtml〉.

75 George Bush, 'Remarks by the President on Iraq and the War on Terror (Transcript)', The White House, 24 May 2004, 〈http://www.whitehouse.gov/news/releases/2004/05/20040524-10.html.

${ }^{76}$ Interviews undertaken by author between June and September 2004 at the Pentagon and Fort Benning, Georgia. 
representation for detainees, and extraordinary rendition, in collaboration with its elite allies as part of a transnational network of terror.

Thus on the one hand, while efforts to secure the right to use torture may, to some extent, have the desired effect of affording its advocates with legitimacy, its use, and efforts to justify its use, also have the effect of delegitimising the elites seeking to use it, particularly among populations targeted by these tactics. It may also further legitimise the cause of the enemies of those that seek to use torture.

\section{Conclusion}

This article has developed a framework to account for torture, consisting of three complementary models. The models show that torture, because of its horribleness, does, to some extent, lend itself to the intended functions of its use. Nevertheless, a key finding of this article is that there is often a disjuncture between the intended functions and actual outcomes of torture.

The security model represents the dominant view of torture, although it actually accounts for a relatively small proportion of all cases. The disjuncture uncovered by the security model is that while it is claimed that torture is intended to secure credible intelligence, on the basis of some cases where it may have yielded results, there is no evidence of its widespread utility for this purpose. Nevertheless arguments are made to legalise and regulate torture for these purposes. Arguments of this kind fail to take into account that the majority of torture has very little to do with intelligence.

The stability model offers an account that explains the majority of cases in which torture is used. Most cases occur in authoritarian states, where torture is intended to intimidate potential or actual political opposition in the hope of maintaining stability in the interests of elites. While this may start out against specific individuals and groups who are made an example of to deter further opposition, the torture very quickly becomes indiscriminate, so that anyone deemed to be the source of potential political opposition may be a victim. This is because torture regimes are very poor at locating their enemies, and tend to target their close associates, initially, but also anyone who has had even fleeting contact with them. In addition, the definition of what constitutes an opponent is very widely interpreted, so that almost anyone can be deemed a potential threat. Torture, when used in this way, is often accompanied by mass murder and detention, and the exile of political opponents. Torture is thus intended as both a deterrent to political opposition, but when coupled with mass murder and mass detention, as a way of literally eliminating potential and actual opposition.

The stability model shows that the distinction between liberal and authoritarian states with regard to torture is not as clear as conventional IR approaches would lead us to believe. While liberal states tend not to use torture in this way domestically, because of the stability afforded by the liberal democratic capitalist system, their use of torture is mostly located in the South. As I have shown, when viewed from the perspective of the connections between various actors across state boundaries, rather than at state-level, the different transnational networks established for specific purposes are exposed. During the Cold War the US operated a terror network in conjunction with elites in the Third World which involved the widespread and 
indiscriminate use of torture. This is one example of a transnational hierarchy in which the US collaborates with other elites in order to secure its own state and elite interests. The involvement of various governments in the policy of extraordinary rendition in the 'War on Terror' can also be thus understood.

The stability model uncovers the disjuncture between the intended and actual outcomes of torture for the purpose of stability. Torture can be effective, at least in the short-term, for ensuring the stability of the regime. In the long term, however, resistance does emerge, often as a consequence of campaigning by exiles which can result in international pressure. On the other hand, in rare cases where the torture is controlled and contained, regimes engaging in its use may enjoy longevity because fewer people are affected, fewer people flee, and external pressure is not sufficient, or because the regime in question enjoys legitimacy afforded through its good relations with dominant liberal states that choose not to challenge them.

The legitimacy model offers an account of the way in which those claiming the right to use torture depend on the assignment of identities to themselves and other actors in order to justify their claim. These identities provide the basis for the legitimacy that advocates of torture seek to secure. In turn, the torture itself is intended to reinforce those identities and therefore the legitimacy of torture's advocates. In this way those advocating torture seek to establish the view that they must be trusted to torture in specific circumstances. At the same time, because the officials are deemed so legitimate, the torture itself is intended to secure their identities and those of the people against whom torture would be used. By being deemed legitimate to use torture, the identities are reinforced.

On the one hand the fear factor involved in this process may cause the public to accept the identities that the advocates of torture seek to establish, therefore reinforcing the legitimacy of those actors. On the other hand, however, this process can have the effect of delegitimising those who attempt to advocate torture, because it is seen to be deplorable and violates liberal norms. It can also lead to increasing opposition to that state in countries where individuals may be targets of the policy, as occurred in Iraq. The disjuncture uncovered by the legitimacy model is that while encouraging more terrorists is not the intention of such a policy, it may well be the outcome, because of the way in which the legitimacy of torture's proponents is undermined. Indeed the terrorists are nevertheless needed in order that the right to use torture is secured and in order for the identity of the proponents of torture to also be secured.

The issues addressed in this article all point towards one final question: should torture be renounced? The answer to this lies in answering whether torture can be deemed necessary for any of the functions it is intended to serve, as well as in making a judgement about the morality of torture. With regard to the securing of intelligence in order to defeat security threats, the answer is no. While torture is occasionally effective for securing credible intelligence, the associated costs of its use - the high chances of torturing individuals who are innocent; the likelihood of acquiring false information; and the danger of torture spreading to the point that it is used indiscriminately for reasons that have nothing to do with security - are far too high. In terms of ensuring stability in the interests of elites, torture as one of various repressive tools is necessary to wipe out political opposition within authoritarian regimes, but in such cases the stability that torture affords for elites is secured through repression, so on liberal grounds, is not a legitimate form of stability. 
Finally, in terms of securing both the legitimacy of the advocates of torture, and the identities on which the process of legitimisation depends, torture is not necessary. Legitimacy can and must be secured by other means. Torture must therefore be condemned, and the models developed here provide a comprehensive basis on which to challenge its use, for they expose both the true functions and the consequences of its use. By exposing the paradoxes of the theory and practice of torture, they also serve to uncover the misunderstandings about torture that lie at the heart of efforts to justify its use. 